\title{
Improving Learning Outcomes Through Make and Match Learning Model for Class 1 SDN Kedunguter 02 Brebes
}

\section{Eti Sarwoniroh}

SDN Kedunguter 02

sarwoniroheti@gmail.com

\section{Article History}

received 3/12/2020

\begin{abstract}
The purpose of this study is to improve the learning outcomes of students in first grade elementary school with the Make And Match learning model. The research was a two-cycle Class Action Research (PTK), with each cycle consisting of two meetings. The stages of each cycle are planning, implementation, observation and reflection. Each meeting is conducted pre test and Post test to know the development of students. In cycle I students completed after doing post test by $76 \%$. In cycle II students who completed after carrying out the post test by 92\%. These results show that the Make And Match learning model can improve the learning outcomes of students at SD Negeri Kedunguter 02 Brebes.
\end{abstract}

Keywords: learning outcome, Make and Match

\section{Abstrak}

Tujuan dari penelitian ini adalah untuk meningkatkan hasil belajar peserta didik di Sekolah Dasar kelas satu dengan model pembelajaran Make And Match. Penelitian yang dilakukan adalah Penelitian Tindakan Kelas (PTK) sebanyak dua siklus, dengan setiap siklus nya terdiri dari dua pertemuan. Tahapan setiap siklusnya adalah perencanaan, pelaksanaan, observasi dan refleksi. Setiap pertemuan dilakukan pre test dan Post test untuk mengetahui perkembangan peserta didik. Pada siklus I peserta didik yang tuntas setelah melakukan post test sebesar $76 \%$. Pada siklus II peserta didik yang tuntas setelah melaksanaakan post test sebesar 92\%. Hasil ini menunjukan bahwa model pembelajaran Make and Match dapat meningkatkan hasil belajar peserta didik di SD Negeri Kedunguter 02 Brebes.

Kata kunci: Hasil belajar, Make and Match

Social, Humanities, and Education Studies (SHEs): Conference Series https://jurnal.uns.ac.id/shes

p-ISSN 2620-9284

e-ISSN 2620-9292 


\section{PENDAHULUAN}

Berdasarkan UUD 1945 Pasal 31 menjadi salah satu landasan penting untuk mengatur keberlangsungan kegiatan pendidikan di Tanah Air. Pasal ini memuat tentang pendidikan dasar masyarakat. Pendidikan Sekolah Dasar merupakan awal peserta didik mendapatkan pembelajaran. Proses pembelajaran yang baik harus disesuaikan dengan karakteristik peserta didik agar dapat dengan mudah memahami materi yang diajarkan dengan baik. Pembelajaran yang dilakukan guru harus kreatif inovatif sehingga peserta didik semangat dan terus aktif dalam belajar.

Kegiatan pembelajaran melibatkan seorang pengajar sebagai fasilitator dan siswa sebagai pembelajaryang dilakukan secara bersama-sama sehingga terjadi proses member dan menerima pengetahuan serta ketrampilan. Ketercapaian dalam berinteraksi bias dilihat dari kegiatan siswa yang ikut aktif mengikuti siklus pembelajaran, dalam pembelajaran yang baik penting adanya dinamika dari setiap peserta didik.

Berdasarkan studi penelitian yang dilakukan di SD Negeri Kedunguter 02 Brebes menemukan beberapa permasalahan yang berkaitan dengan pembelajaran. Melalui wawancara wali murid kelas 1 tanggal 20 Juli 2020 pemebelajaran yang dilakukan kurang maksimal dikarenakan pembelajaran berpusat pada guru atau teacher center Learning, sarana dan pra sarana yang kurang mendukung sehingga siswa kurang tertarik pada pemebelajaran selain itu siswa kurang percaya diri, rendahnya keaktifan siswa dalam belajar.selanjutnya untuk meningkatkan keaktifan siswa, hasil perhitungan skor menunjukan jika kondisi dasar atau pra siklus adalah 48\% (rendah) dari 25 peserta didik.

Model pembelajaran menurut Joyce \& Weil dalam Huda (2013: 73) berpendapat bahwa " Model pembelajaran sebagai rencana atau pola yang dapat digunakan untuk membentuk kurikulum, mendesain materi-materi instruksional dan memandu proses pengajaran diruang kelas atau di ruang berbeda." Model pembelajaran mengacu pada pendekatan yang akan digunakan termasuk didalamnya tujuan-tujuan pembelajaran, lingkungan pembelajaran, dan pengelolaan kelas, mengemukakan maksud dari model pembelajaran adalah kerangka konseptual yang melukiskan prosedur yang sistematis dalam mengorganisasikan pengalaman belajar untuk mencapai tujuan belajar tertentu, dan berfungsi sebagai pedoman bagi para perancang pembelajaran dan para pengajar dalam merencanakan aktivitas belajar mengajar.

Model pembelajaran Make And Match (mencari Pasangan) dikembangkan oleh Lorn Curran pada tahun 1994 pada model ini siswa diminta mencari pasangan dari kartu, Aqib Zainal (2013 : 23). Menurut Tarmizi dalam Novia (2015 : 12) menyatakan bahwa model pembelajaran Make And Macth artinya siswa mencari pasangan setiap siswa mendapat sebuah kartu (bisa soal atau jawaban) lalu secepatnya mencari pasangan yang sesuai dengan kartu yang ia pasang. Penerapan Model pembelajaran Make And Macth dalam proses belajar mengajar (1) tahap persiapan (2) tahap penyampaian (3) penampilan hasil.

Penggunaan model pembelajaran harus sesuai dengan materi yang disampaikan, jika tidak sesuai maka tujuan pembelajaran yang diinginkan tidak akan tercapai. Hasil belajar juga akan rendah karena peserta didik tidak memahami materi pelajaran yang disampaikan. Pada peserta didik kelas satu SD Negeri Kedunguter 02 Brebes. Dari penelitian ini ditemukan jika model pembelajaran melibatkan kemampuan berfikir siswa untuk menemukan dan menyelidiki secara sistematis, logis dan kritis yang akan meningkatkan hasil belajar motivasi dan keaktifan pada setiap siklus. Berdasarkan identifikasi masalah peneliti berharap bias melakukan penelitian tindakan kelas dengan judul Peningkatan Hasil Belajar Melalui Model Pembelajaran Make And Macth Untuk Kelas Satu SD Negeri Kedunguter 02 Brebes . 


\section{METODE}

Penelitian ini adalah Peneliyian Tindakan Kelas (PTK) dengan menerapkan Model Pembelajaran Make And Mcth. Menurut Kurt Lewin merupakan model PTK yang pertama kali ada. Komponen pokok yang dilakukan pada Model PTK Kurt Lewin meliputi (1) Prencanaan (2) Tindakan (3) Pengamatan (4) Refleksi. Analisi penelitian ini adalah analisis deskripsi kuantitatif kualitatif. Penelitian ini dilaksanakan pada peserta didik kelas 1 SD Negeri Kedunguter 02 Brebes Tahun Pelajaran 2020/2021 selama dua siklus secara Luring dengan 2 pertemuan di setiap siklusnya. Teknik pengumpulan data dilakukan dengan observasi dan tes baik pre test maupun post test. Observasi meliputi obesrvasi keterlaksanaan model pembelajaran Make And Macth, sikap peserta didik dan ketrampilan. Untuk hasil belajar teks melalui pembelajaran Luring.

Teknik pengumpulan data yang digunakan dalam penelitian ini menggunakan alat bantu instrument wawancara, formulir observasi,dan angket kinerja guru. Data kualitatif tersebut diperoleh dalam bentuk komentar dan saran pengamat, dimana selanjutnya akan dijabarkan dalam bentuk skor evaluasi observasi kinerja guru dalam deskripsi kualitatif, meliputi kemampuan dan ketrampilan guru dalam mengajar dengan menggunakan model pembelajaran Make And Macth dan kegiatan belajar peserta didik. Data kuantitatif di peroleh dari lembar observasi keaktifan peserta didik dan kinerja guru yang telah mengikuti proses pembelajaran, dilakukan dengan membandingkan data siklus I dan siklus II.

\section{HASIL DAN PEMBAHASAN}

Pada siklus I pembelajaran dilaksanakan selama dua pertemuan, setiap pertemuan diadakan pre test dan post test. Untuk mengetahui perkembangan peserta didik selama pembelajaran dilaksanakan tanggal 21 dan 22 Juli 2020. Siklus I membahas materi tentang bagian-bagian anggota tubuh dan fungsinya. Melalui kartu yang berisi gambar bagian anggota tubuh dan kartu selanjutnya fungsi dari anggota bagian tubuh. Berikut ini adalah hasil belajar peserta didik pada siklus I yang bisa dilihat pada table berikut.

Tabel 1. Hasil Belajar Peserta Didik Siklus I

\begin{tabular}{ccccccccc}
\hline \multirow{2}{*}{ Siklus I } & \multicolumn{4}{c}{ Pre test } & \multicolumn{3}{c}{ Post test } \\
\cline { 2 - 9 } & \multicolumn{2}{c}{ Tuntas } & \multicolumn{2}{c}{ Belum Tuntas } & \multicolumn{2}{c}{ Tuntas } & \multicolumn{3}{c}{ Belum tuntas } \\
\cline { 2 - 7 } & Jumlah & $\%$ & Jumlah & $\%$ & Jumlah & $\%$ & Jumlah & $\%$ \\
\hline Pertemuan 1 & 10 & $40 \%$ & 15 & $60 \%$ & 18 & $72 \%$ & 7 & $28 \%$ \\
Pertemuan 2 & 15 & $60 \%$ & 10 & $40 \%$ & 22 & $88 \%$ & 3 & $12 \%$ \\
\hline
\end{tabular}

Berdasarkan tabel diatas maka terjadi peningkatan antara pre test dan post test pada pertemuan 1. Setiap individu peserta didik sudah mengalami peningkatan hasil belajarnya seperti pada pre test yang tuntas $40 \%$ sedangkan post test $80 \%$. Terjadi peningkatan pada pertemuan 2. Setiap individu peserta didik sudah mengalami peningkatan hasil belajarnya seperti pada pre test yang tuntas $60 \%$ sedangkan sedangkan post test $88 \%$. Perbandingan antara hasil post test pertemuan 1 dan pertemuan 2 terdapat perbedaan. Pada pertemuan 1 peserta didik yang tuntas hanya 20 anak. Sedangkan pada pertemuan 2 peserta didik yang tuntas sudah meningkat menjadi 22 anak.presentasi ketuntasan klasikalnya meningkat jika pertemuan 1 hanya $72 \%$ maka pada pertemuan 2 menjadi $88 \%$.

Berdasarkan refleksi pada siklus I maka diputuskan untuk melanjutkan ke siklus II dikarenakan belum mencapai ketuntasan klasikal yang diharapkan. Pada siklus II membahas materi tentang menyebutkan bagian-bagian anggota tubuh dan fungsinya . pembelajaran dengan model Make And Macth diharapkan mampu menyusun bagian 
anggota tubuh beserta fungsinya. Berikut ini adalah hasil belajar peserta didik yang siklus II yang bisa dilihat pada tabel berikut.

Tabel 2. Hasil Belajar Peserta Didik Siklus II

\begin{tabular}{ccccccccc}
\hline \multirow{2}{*}{ Siklus II } & \multicolumn{4}{c}{ Pre test } & \multicolumn{4}{c}{ Post test } \\
\cline { 2 - 9 } & \multicolumn{2}{c}{ Tuntas } & \multicolumn{2}{c}{ Belum Tuntas } & \multicolumn{2}{c}{ Tuntas } & \multicolumn{3}{c}{ Belum tuntas } \\
\cline { 2 - 5 } & Jumlah & Jumlah & $\%$ & Jumlah & $\%$ & Jumlah & $\%$ \\
\hline Pertemuan & 12 & $48 \%$ & 13 & $52 \%$ & 23 & $92 \%$ & 2 & $8 \%$ \\
$\begin{array}{c}\mathbf{1} \\
\text { Pertemuan } \\
\mathbf{2}\end{array}$ & 17 & $68 \%$ & 8 & $32 \%$ & 24 & $96 \%$ & 1 & $4 \%$ \\
\hline
\end{tabular}

Berdasarkan table diatas maka terjadi peningkatan antara pre test dan post test pada pertemuan 1. . Setiap individu peserta didik sudah mengalami peningkatan hasil belajarnya seperti pada pre test yang tuntas $48 \%$ sedangkan post test $52 \%$. Terjadi peningkatan pada pertemuan 2. Setiap individu peserta didik sudah mengalami peningkatan hasil belajarnya seperti pada pre test yang tuntas $68 \%$ sedangkan sedangkan post test $96 \%$. Perbandingan antara hasil post test pertemuan 1 dan pertemuan 2 terdapat perbedaan. Pada pertemuan 1 peserta didik yang tuntas hanya 23 anak. Sedangkan pada pertemuan 2 peserta didik yang tuntas sudah meningkat menjadi 24 anak.presentasi ketuntasan klasikalnya meningkat jika pertemuan 1 hanya $92 \%$ maka pada pertemuan 2 menjadi $96 \%$. Dari dua siklus yang sudah dilaksanakan selama 4 pertemuan dapat dipastikan bahwa model pembelajaran Make And Macth dapat meningkatkan hasil belajar peserta didik kelas 1 SD Negeri Kedunguter 02 Brebes. Menurut Suprijono model pembelajaran kooperatif tipe Make And Macth adalah suatu model pembelajaran yang dilakukan dengan mencari pasangan melalui kartu-kartu sehingga meningkatkan keaktifan peserta didik untuk mencapai hasil belajar yang klasikal.

\section{SIMPULAN}

Penerapan model pembelajaran Make And Macth dapat meningkatkan hasil belajar peserta didik kelas 1 SD Negeri Kedunguter 02 Brebes pada Tema 1 Diriku tahun pelajaran 2020/2021 semester 1 terjadi peningkatan skor keaktifan belajar siswa, pra siklus adalah $48 \%$ (rendah), setelah diterapkan nya model pembelajaran Make And Macth mengalami peningkatan pada siklus I menjadi $80 \%$ (tinggi) dan meningkat lagi pada siklus II menjadi 92\% (tinggi). Upaya peningkatan keaktifan pembelajaran siswa materi bagian-bagian anggota tubuh dan fungsinya. Peningkatan yang terjadi karena model pembelajaran Make And Macth memiliki kelebihan diantaranya (1) mampu menciptakan suasana aktif dan menyenangkan (2) materi pembelajaran yang disampaikan lebih menarik perhatian siswa (3) suasana kegembiraan akan tumbuh dalam proses pembelajaran.

Berdasarkan pengalaman penulis dalam melaksanakan penelitian di kelas 1 SDN Kedunguter 02 Brebes ada beberapa saran dan tindak lanjut yang dapat penulis sampaikan sebagai berikut :

Sebagai guru, hendaknya dalam proses pembelajaran menggunakan media yang tepat dan menarik perhatian peserta didik sehingga dapat meningkatkan motivasi peserta didik dalam proses pembelajaran.

Sebagai peserta didik, hendaknya jangan ragu-ragu dalam menggunakan media pembelajaran untuk meningkatkan pengetahuan dan pengalamannya. Peserta didik juga lebih aktif, kreatif dan disiplin dalam meningkatkan prestasinya. 
DAFTAR PUSTAKA

Apriliyani(2016) Pengaruh Model Cooperative Learning Tipe Make A Match Dalam Pembelajaran Ipa Terhadap Keterampilan Sosial Dan Hasil Belajar Kognitif Siswa SMP. Jurnal Pendidikan IImu Pengetahuan Alam Vol. 5 No. 9 hal 1-7 Aqib Zaenal(2016). Model -Model, Media dan Strategi Pembelajaran Kontekstual (Inovatif).YramaWidya. Bandung

Daryanto, Karim Syaiful(2017). Pembelajaran Abad 21. Gava Media. Yogyakarta.

Fatkhan.2017.https://fatkhan.web.id/pengertian-dan-langkah-langkah-modelpembelajaran-make-match/

Kumandar, 2011. Langkah Muda Penelitian Tindakan Kelas Sebagai Pengembang Profesi guru. Jakarta: PT Raja Grafindo Persada.

Sudjana, N. 2009. Penilaian Hasil proses Belajar Mengajar. ( Cetakakn ketigabelas). Bandung: PT. Remaja Rosdakarya.

Undang - undang Republik Indonesia Nomor 20 Tahun 2003 tentang Sistem Pendidikan Nasional. Bandung: Citra Umbara.2006 Undang -undang 1945.https://kumparan.com/berita-hari-ini/bunyi-uud-1945pasal-31-dan-maknanya-1vFCmGZzh5e 